\title{
Facing Fear and Responding with Courage: Understanding How Fear Constitutes the "Emotional Citizenship" of Voluntary Returnees to Bosnia and Herzegovina
}

DOI: https://doi.org/10.11567/met.35.2.3 UDK: 316.613.4+314.151.3(497.6) Izvorni znanstveni rad Primljeno: 25.11.2018. Prihvaćeno: 06.11.2019.

\section{Aida Ibričević ${ }^{1}$}

Sarajevo

ibricevic@gmail.com

\section{SUMMARY}

This paper examines the case of voluntary return migration to a post-conflict society, such as Bosnia and Herzegovina $(\mathrm{BiH})$, where the returnee freely chooses to go back despite having a viable alternative of livelihood and a well-integrated social presence abroad. The initial claim of the paper is that the motivation for this type of return is primarily emotional. Although the much researched (Brown, 2014) "patriotic love" is certainly part of returnees' emotional landscape, other emotions play an equal, and sometimes a more important role. Arguing that fear is a key emotion constituting returnees' daily experience of $\mathrm{BiH}$ citizenship, the paper identifies three dimensions of fear: ethnic discrimination, economic uncertainty and abuse of political power. Returnees' continued life and work in the home state represent an act of remarkable courage, the success of which does not occur because of the state structure envisioned by the Dayton Peace Agreement (DPA) that comprises the current $\mathrm{BiH}$ Constitution, but in spite of the obstacles it creates. The argument is based on a thematic analysis of 35 in-depth interviews conducted with members of the Bosnian and Herzegovinian diaspora/transmigrants, who have voluntarily decided to return and settle in $\mathrm{BiH}$.

KEY WORDS: emotional citizenship, fear, home, belonging, return migration, Bosnia and Herzegovina.

This paper is part of the author's Ph.D. thesis, Searching for Home and Belonging: A Qualitative Study to Understand the "Emotional Citizenship" of the Diaspora Returning to Bosnia and Herzegovina, theorising the emotional citizenship of the diaspora voluntarily returning to a post-conflict society. 


\section{INTRODUCTION}

Where we love is home - home that our feet may leave, but not our hearts. Oliver Wendell Holmes Sr.

The quote by Oliver Wendell Holmes Sr., a U.S. writer and poet, is prominently displayed on the website of RESTART, a Sarajevo-based company established to facilitate joint ventures as well as diaspora return and investment in Bosnia and Herzegovina (BiH). ${ }^{2}$ The juxtaposition of the "love for home", particularly when the home is in a post-conflict society, and a forprofit business enterprise might be confusing at first. Yet, when confronted with the harsh reality of life in Bosnia and Herzegovina, mere confusion turns into a true puzzle. In $\mathrm{BiH}$, the conditions for mass emigration are created through a combination of a dysfunctional and highly inefficient state apparatus, a society deeply divided along ethno-religious lines, and an economic environment characterised by low growth, high unemployment, and high levels of crime and corruption.

Collyer (2013) ranks Bosnia and Herzegovina in second place, behind Albania, in terms of the size of the emigrant population relative to the total population of Europe. According to more recent estimates (UNDP, 2014), close to two million citizens originating from $\mathrm{BiH}$ or approximately one half of the pre-war population currently live and work abroad. This places $\mathrm{BiH}$ at the top of the list of net (relative to total population) emigration countries in Europe. Forced migration during the 1990s wars in the former Yugoslavia, together with largely failed policies for sustainable refugee return, is mostly responsible for the numerousness of the $\mathrm{BiH}$ diaspora. However, even after twenty-three years of peace and the "failed success" (Bieber, 2015), people of all ethnic backgrounds: Bosniaks, Croats, Serbs, and others are leaving this small European country in droves to find employment and opportunities elsewhere. A youth unemployment rate of 55.4\% (World Bank, 2017a), close to being the highest in the world, and nepotistic employment practices are also contributing factors to the startling numbers of $\mathrm{BiH}$ citizens leaving the country.

Within the general trend of alarming emigration rates, a small number of people are deciding to do exactly the opposite. They are leaving the relatively secure lives they managed to establish for themselves abroad, mainly in developed countries of the West, to return and settle in Bosnia and Her-

2 See: Working for the Economic Prosperity of the Nation, Restart.ba, April 28, 2017, http:// restart.ba/video/. 
zegovina. The people returning to $\mathrm{BiH}$ are members of the diaspora which was created by forced migration following the collapse of Yugoslavia, but also descendants of previous labour migration waves. They have lived in various countries, established lives and careers abroad and gained citizenship of the host countries. Now, they are returning to try to make a life for themselves in the country of their original citizenship. What causes puzzlement is a sense of contradiction. Why would people with apparent alternatives for livelihood be coming back to a country from which so many people seem to be desperately running away? What motivates their seemingly irrational move from stable Western democracies such as Austria, Norway or Germany to a country still recovering from the aftermath of a devastating war?

The argument presented in the study is that the motivation to return to a post-conflict society like Bosnia and Herzegovina is primarily emotional. This is particularly true in the case of voluntary return, where the returnee freely chooses to go back despite a viable alternative of livelihood and a well-integrated social presence abroad. Although the much researched (Brown, 2014) "patriotic love" is certainly part of the returnees' emotional landscape, other emotions play an equal, and in some cases a more important role. They are highly complex, ranging from fear, guilt, shame, denial, rage, anger, frustration, disgust, pity and powerlessness to defiance, joy, happiness, pride, nostalgia, and hope. The actual reasons for the existence of these emotions are context-specific, requiring an understanding of the particular context of Bosnia and Herzegovina. However, emotions also have a universal quality. Regardless of their political context, humans know what it means to feel scared, ashamed, joyful, nostalgic or hopeful. Besides, their emotions towards political phenomena, such as citizenship, are not just purely personal responses. They form a collective reality and thus constitute the human experience of the "political".

Following intense academic debates on the subject, ${ }^{3}$ the study is anchored in two underlying premises regarding the nature of emotions and understanding social reality. Firstly, the study does not place emotions in stark opposition to rationality, nor does it dismiss them as purely irrational. Instead, emotions are given their rightful place in the analysis and are seen as

\footnotetext{
See Bleiker and Hutchinson (2008) for a summary of the scholarly debate between the "bodily/somatic approach" to emotions and the alternative "cognitive/appraisal approach". See Hutchinson and Bleiker (2007) for a synthesis of explanations of why the study of emotions has been sidelined from the social sciences due to being perceived as purely personal and thus not worthy of political analysis.
} 
"important forms of knowledge and evaluative thought" (Nussbaum, 1995, in Bleiker and Hutchinson, 2008: 124). Secondly, emotions are not considered purely personal reactions, but rather crucial for a better understanding of social reality with full respect towards their diversity and distinctiveness. The study assumes that emotions have an important place in politics and society, particularly "in the process of constituting identity and community attachments" (Hutchinson and Bleiker, 2007: 63).

The unifying conceptual framework chosen for the study is citizenship, also seen as a "prism through which to address the political" (Nyers, 2007: 3) and, more specifically, its emotional dimension, thus far conceptualised through the home and belonging in the relevant literature. Although these concepts apply to all citizens of a state, returning diaspora members are in a particularly apt position to further our conceptual understanding, as they have a basis for comparison between the home and the host state. As Portes, Guarnizo and Landolt (1999: 217) point out, transmigrants are most often people who "live dual lives: speak two languages, have homes in two countries and make a living through continuous regular contact across national borders". Following the assertion that transmigrants' return to a post-conflict society is emotionally driven, the duality of their overall life experience makes them uniquely positioned to give substance and meaning to the unifying concepts of this study: citizenship, particularly its emotional dimension.

This study argues that fear is a key emotion constituting returnees' daily experience of $\mathrm{BiH}$ citizenship and that the continuation of life and work in the home state is an act of remarkable courage. If the returnees are having any success in building a sustainable life in $\mathrm{BiH}$, it is not because of the state structure envisioned by the Dayton Peace Agreement (DPA), comprising the current $\mathrm{BiH}$ Constitution, but in spite of the obstacles it creates. The DPA Constitution establishes a two-tiered model of $\mathrm{BiH}$ citizenship, derived from BiH being composed as an asymmetrical federation where the territorial autonomy of the two entities, Republika Srpska and the Federation of Bosnia and Herzegovina, is supplemented by consociational power-sharing (Džankić, 2015) between the three ethnic groups (Croats, Bosniaks, and Serbs) or "constituent peoples", as they are referred to in the Constitution. The Dayton Peace Agreement ended a devastating war and, as such, necessarily result resulted from the negotiation of a compromise. However, this compromise was not attained through internal political bargaining. Rather, as Džankić (2015) rightly points out, it was imposed from the outside. Apart 
from Bosnia and Herzegovina, it was also ratified by Croatia and Serbia. The resulting state structure and citizenship regime, as created on the grounds of the Wright-Patterson Air Force Base near Dayton, Ohio, ultimately led to Bosnia becoming a "failed success" (Bieber, 2016).

The findings are based on the grounded theory method of analysis of 35 in-depth interviews conducted with returnees to $\mathrm{BiH}$, relying mainly on its open coding stage. The paper argues that fear is a key element of the emotional dimension of $\mathrm{BiH}$ citizenship, with ethnic intolerance, economic uncertainty and the abuse of political power being its three main sources.

\section{EMOTIONAL CITIZENSHIP, HOME, AND BELONGING}

The concept of emotional citizenship refers to how individuals perceive citizenship as a feeling, rather than as a set of rights and duties presented by the state and politically received by the citizen. Directly connecting emotions and the state and arguing that the "affective is the substance of politics", Laszczkowski and Reeves (2015: 2) look at how "affective states" (Stoler, 2007) relate an array of emotions, feelings and affects to state formation, development, continuation, and weakening. Emotional citizenship relies heavily on citizenship as a practice (Wood, 2013), that is, on the daily experience of citizenship (Nyers, 2007). The complexity of citizenship is most pronounced within everyday life, where it is experienced as a feeling and not necessarily a politically structured one (De Graeve, 2010). To give an analytical rigour to the concept of emotional citizenship, Ho (2009) differentiates between emotional representations and emotional subjectivities. Emotional representations are defined as the "lexicon and metaphors that individuals use to give meaning to citizenship, such as 'home' and 'belonging'" (Ho, 2009: 789), while emotional subjectivities "emphasize the way individuals experience the social world, especially the manner in which they emotionally negotiate the power relations of citizenship governance" (Ho, 2009: 789). These two categories are not mutually exclusive; they rather constitute each other. Similarly, Jackson (2016) finds that the four main elements of emotional citizenship are: belonging, home, safety, and roots, with the home being "intrinsic to emotional citizenship" (Jackson, 2016: 824). Other authors (Magat, 1999; Wood, 2013; Howes and Hammett, 2016; Ahmed, 2016) place the focus of emotional citizenship on belonging or a feeling of belonging. According to Yuval-Davis, Kannabirān and Vieten (2006), the politics of belonging connects citizenship and identity on the one side, and the ways in 
which the state and society relate to individuals and groups by adding an emotional dimension, essential to belonging, on the other.

Scholars of contemporary Bosnia and Herzegovina have looked at the relationship between the affective sphere and the state, society, and citizenship from different perspectives. Brković (2015: 271) explores how clientelism and patronage (veze and stele) manifest themselves in post-war $\mathrm{BiH}$, namely in the town of Bijeljina, by focusing on "the logic of ethics, compassion and humanitarian sentiment - quite different from the logic of citizenship rights". One of the key findings in Brković (2015) is that the major transfer of responsibility for welfare protection from the state to local communities created an ambiguity regarding who in the local community is responsible for implementing these policies and whether this is a legal duty of the state or a question of individual goodwill, thus creating a fertile ground for clientelism and patronage. Based on research conducted in an apartment complex in a Sarajevo suburb, instead of ambiguity in the relations between the state and citizens, Jansen (2015) found a major yearning of $\mathrm{BiH}$ citizens for stability, certainty, predictability and a return to "normal lives". Hromadžić (2015: 61) uses ethnographic evidence from the Mostar Gymnasium to explore how the Dayton Peace Agreement has "emptied" the notions of "state" and "nation" by simultaneously encouraging local and international forces of segregation and integration to create a "detachment of citizens from a common state". Helms (2013: 33) investigates the relationship between the concepts of innocence and victimhood and the manners in which they "structured the possibilities and obstacles for gendered citizenship and women's activism".

Once a theoretical connection between emotions and citizenship is established, the following question emerges: which particular, specific and distinct emotions constitute citizenship? As pointed out by other scholars, such as MasGiralt (2015), a sorely missing element in theorising the emotional dimension of citizenship is an exploration of its distinct constituent. The few notable exceptions are investigations of the most common emotion connected to citizenship, "patriotic love", and its opposite - hatred for the enemy of the country, nation or the state (Brown, 2014; Ahmed, 2014; Franz, 2015; Patti and van Zoonen, 2006). Apart from "patriotic love", scholars have also examined the nexus between citizenship and the feelings of fear (Fortier, 2010; Ho, 2009; Isin, 2004; Johnson, 2010), security/safety (Jackson, 2016; Skulte-Ouaiss, 2013; Yuval-Davis, 2006), and shame (Brown, 2014; Aguilar, 1996). This paper contributes to the scholarly debate on how fear 
constitutes citizenship, as illustrated by return migration to a post-conflict society - Bosnia and Herzegovina. Specifically, it argues that the way in which fear constitutes the citizenship of $\mathrm{BiH}$ originates in ethnic intolerance, economic uncertainty and the abuse of political power. Each of the dimensions of fear derives from the Constitution of the state and its resulting citizenship regime.

\section{RETURN MIGRATION TO POST-WAR BOSNIA AND HERZEGOVINA}

As Dahlman and Ó Tuathail (2005: 582) rightly assert, when considering post-war return migration to Bosnia and Herzegovina, it is important to emphasise the "contradiction in the Dayton Peace Agreement between the partition of Bosnia into de facto monoethnic spaces and the peace plan's guaranteed that the displaced could return to their pre-war homes". On the one hand, the two entities have been formed as a result of ethnic cleansing and genocide and the peace treaty itself more or less legalised the status quo established by the war, while at the same time the peace agreement seemingly provided for the tenuous possibility of reversing the effects of war. The right of return is provided in Annex 7, Chapter 1, Article 1 of the Dayton Peace Agreement: "All refugees and displaced persons have the right freely to return to their homes of origin. They shall have the right to have restored to them property of which they were deprived in the course of hostilities since 1991 and to be compensated for any property that cannot be restored to them". The glaring contradiction inherent in the Dayton Peace Agreement was additionally compounded by the fact that the security of the return of minorities was entrusted to the same authorities responsible for their expulsions in wartime (Alvarez, 2015). Despite the obvious contradictions, the return of refugees and displaced persons to their pre-war homes was viewed by the international community as essential to the viability of Bosnia and Herzegovina as a multi-ethnic state (Stefansson, 2006).

The key to rebuilding BiH's pre-war multi-ethnic composition was the concept of "minority returns" - the return of displaced persons and refugees to areas where they would now be in a numerical minority, according to their ethnicity. However, the actual dynamic of return was such that the favoured "majority return" from abroad, most intense during the first two years after the war (Pašić, 2015), and the implementation of the DPA's Annex 7 did not result in long-term success. To fully understand the failures to implement the Annex 7 provisions of the Dayton Peace Agreement, it is important to 
compare and contrast minority/majority return with a sustainable return. As Eastmond (2006) points out, the success of return was to a great extent determined by economic opportunities, even in the case of majority return. In other words, even if the returnee faces no direct obstacles to social integration due to his/her ethnicity, the economic reality of nearly every other person of working age being unemployed still looms large. According to UNHCR estimates, $93 \%$ of the property lost in the war was restituted by May 2005. Yet, the number of formally registered returnees is much higher than the number of actual physical returns (Eastmond, 2006). Therefore, people merely returning to reclaim or reconstruct their property, whether they belong to ethnic majorities or minorities, cannot be considered sustainable. Sustainable return implies the possibility of returnees to generate an income; provide a livelihood for their families and "build communities in conditions of geographic or social marginalization" (Dahlman and Ó Tuathail, 2005: 582). Despite the success in property restitution, sustainable return in Bosnia and Herzegovina, be it majority or minority, remains an overall failure.

\section{METHODOLOGY}

Thirty-five in-depth interviews were conducted during the summer and fall of 2017 in cities and towns throughout Bosnia and Herzegovina. During the fieldwork, the author was based in Sarajevo and made trips to the various places where the study participants live and work: Prijedor, Banja Luka, Kozarac, Sanski Most, Velika Kladuša, Trebinje, Ljubuški, Mostar, Nevesinje, Derventa, Gračanica, Maglaj, Počitelj, Jajce, and Srebrenica. As was mentioned previously, the most important criterion to recruit study participants was the nature of their decision to return to $\mathrm{BiH}$ : they had to have freely chosen to return despite a viable alternative of staying in the host state. In that sense, their return was "voluntary" and not a product of any kind of political, economic or social pressure. Some of them left their home country as refugees during the 1990s wars while others are descendants of labour migrants who had left the country between the 1960s and 1970s. The interviewees have returned to Bosnia and Herzegovina from a variety of host countries such as Germany, the US, Switzerland, Turkey, Australia or Italy, and are now fully-contributing members of BiH society, actively employed, self-employed or creating jobs for others. They currently reside in both the Federation of Bosnia and Herzegovina and Republika Srpska ("Serb Republic"), in large city centres, such as Sarajevo, as well as smaller towns, such as Nevesinje or Gračanica. 
Using theoretical sampling, the sample grew to include participants of all ethnicities, including variations within ethnic groups, all religious groups present in $\mathrm{BiH}$ with differing levels of religiosity, and both majority and minority returnees. The dataset, consisting of close to 700 pages of interview transcripts, was imported into NVIVO 11 and analysed using the Strauss and Corbin (1998) approach to grounded theory. The accompanying fieldnotes and a reflective journal were used for triangulation. In addition to a set of deductive codes derived from the conceptual framework, an inductive thematic coding scheme was developed. The resulting coding scheme identified particular emotions and emotional responses constituting the returnees' understanding of $\mathrm{BiH}$ citizenship, as well as various aspects of their conceptualisation of home and belonging. Qualitative data analysis revealed a set of highly complex emotions ranging from rage, anger, and frustration to fear, guilt, denial, disgust, shame, disappointment, pity, and empathy, to nostalgia and powerlessness. On the opposite side of the emotional spectrum, the prominently featured emotions in the dataset were patriotic love, pride, defiance, joy, happiness, and hope. The following section presents the results of the data analysis regarding the emotion of fear and provides both a descriptive and interpretive account of how this emotion relates to citizenship.

\section{FEAR CONSTITUTING THE EMOTIONAL DIMENSION OF BIH CITIZENSHIP AND THE COURAGEOUS RESPONSE}

The analysis identifies three sources of fear as it constitutes BiH citizenship: ethnic intolerance, economic uncertainty, and the abuse of political power. Scholarly literature on Bosnia and Herzegovina, as well as media reports, are saturated with writings on the prevalence of fear felt by one ethnicity of another. Yet, while this paper acknowledges the presence of the ethnicitybased fear, it argues that it is not the only one and possibly not even the dominant one. The argument is that the three dimensions of fear originate in the constitutional setup of the state and the two-tiered citizenship regime, both of which are part of the Dayton Peace Agreement. Firstly, the Dayton Peace Agreement (DPA) ended a horrific war and, although envisaged as a consociational power-sharing arrangement, in reality, it legalised genocide and ethnic cleansing. Thus, the agreement recognised a de-facto division of Bosnia and Herzegovina, providing a basis for the continuation of the ethnicity-based fear. Secondly, the DPA set up a hugely inefficient administrative structure and public sector that are not conducive to eco- 
nomic development and growth, instilling economic insecurity and fear of poverty among $\mathrm{BiH}$ citizens. For a country of 3.8 million people, the DPA Constitution institutes thirteen parliaments (state, entity and cantonal) with thirteen governments and close to two hundred government ministries. The incredibly complicated and dysfunctional public administration created by the Dayton Peace Agreement suffocates the minuscule economy with a GPD of only USD 4,771 per capita (World Bank, 2017b). Thirdly, the fear of the abuse of political power is a unique dimension of fear as it constitutes $\mathrm{BiH}$ citizenship. The inefficiencies of the $\mathrm{BiH}$ state structure make room for ample corruption, racketeering and intimidation to thrive. Under such circumstances, it is the oligarchic political power of the ethnonationalist elites, and not the rule of law, that determines the livelihood and wellbeing of each $\mathrm{BiH}$ citizen, independent from his or her ethnic, religious, and even socio-economic background.

The fear of renewed violence and ethnic conflict is a part of daily life in Bosnia and Herzegovina. Fascist symbolism and imagery keep the ethnicitybased fear alive, occurring in many different shapes and forms. The countless examples range from the appearance of the Srbe na vrbe ${ }^{4}$ graffiti in the Vrace neighbourhood of Sarajevo, the burning of an effigy of ICTY President Judge Carmel Agius in Livno, ${ }^{5}$ the frequent chanting of slogans at football matches such as: Gazi balije, Nož, žica, Srebrenica ${ }^{6}$, and Za dom spremni ${ }^{7}$. They even include statements made by officials in power, such as the RS President, Milorad Dodik, professing that "Ratko Mladić is a true hero and

4 The phrase "Srbe na vrbe" is an example of hate speech directed against Serbs. Translated, it means "(Hang) the Serbs from the willow trees". The graffiti appeared spray-painted on a supporting wall in April 2015 and was quickly re-painted by a group of outraged Sarajevo citizens. For more on this incident, see Ne primitivizmu: Samir Hodović iz benda Velahavle prekrečio uvredljivi grafit na Vracama, https://www.klix.ba/vijesti/bih/ne-primitivizmusamir-hodovic-iz-benda-velahvale-prekrecio-uvredljivi-grafit-na-vracama/150423131.

5 The event occurred at a children's festival in February 2018 in response to the ICTY's (International Criminal Tribunal for Yugoslavia) final verdict in the Prlić et al. Appeals case. The ICTY convicted Prlić, Stojić, Praljak, Petković, Ćorić, and Pušić of crimes against humanity, violations of the laws and customs of war, and grave breaches of the Geneva Convention.

6 Balije is a derogatory term for Bosniaks. The slogan Gazi Balije means "Stomp out the Balije". Literally translated, the phrase Nož, žica, Srebrenica means "Knife, barbed wire, Srebrenica". Both phrases are examples of hate speech directed against Bosniaks.

7 The literal translation of the slogan Za dom spremni! is "For home(land) - ready!". It was used during World War II by members of the Ustaše movement as an official salute of the Independent State of Croatia (Croatian: NDH), analogous to the Nazi Sieg Heil!. Za dom spremni has recently been a subject of considerable controversy in Croatia. A thorough discussion of this controversy is beyond the scope of this paper; however, Za dom spremni was used solely as an Ustaša salute in the context addressed by this paper. 
a patriot ${ }^{8 \prime \prime}$. The participants in this study live and work in the social reality described above and suffer its consequences together with all the other citizens. Alma ${ }^{9}$ is a child psychologist, who returned from Germany and established a childcare centre in Sarajevo. She identifies as a Bosnian-Herzegovinian citizen and an agnostic, rejecting any ethnic or religious labels in her self-identification. She was asked how she felt as a BiH citizen when she travelled through different parts of Bosnia and Herzegovina. In response, she turned the discussion to her experiences in the Serb-dominated areas of the country.

Alma: Well, since we are divided into two... I cross the hill to go to East Sarajevo, where I have my dear friends and I walk down a street called Ulica srpskih heroja [Serbian Heroes Street], or another one called Vidovdanska ulica [St. Vitus Day ${ }^{10}$ Street].

Author: How do you feel as you walk down these streets?

Alma: Very strange, because after all aren't we in Bosnia and Herzegovina? The names of these streets are more Serb-sounding than the names of streets in Belgrade.

Author: So, how do you feel because of that?

Alma: Angry, disappointed, and yes, afraid. And it's not like we haven't tried to do something differently. Both I and my husband decided that we would take the kids skiing to Jahorina, only to show our children that Jahorina is just as much ours as is Bjelašnica ${ }^{11}$. We keep going to Jahorina where Serbian flags are displayed everywhere, Serbian holidays are celebrated and everything is closed on 9 January. There are other parts of the country, like Romanija ${ }^{12}$, where I really don't think

8 The statement was made in response to the ICTY convicting Ratko Mladić, former Commander of the Main Staff of the Bosnian Serb Army (VRS), of genocide, crimes against humanity and violations of the laws and customs of war. For background on this statement, see "Dodik: Mladić istinski heroj i patriota", https://www.slobodnaevropa. org/a/28870085.html. For more on reactions to the Mladić verdict, see Vulliamy, Ed (2017) "Ratko Mladić will die in jail. But go to Bosnia and you will see that he has won", https:// www.theguardian.com/commentisfree/2017/nov/22/ratko-mladic-bosnia-camps-massmurder-torture-rape-serbian

9 All names used in the study are pseudonyms.

10 St. Vitus Day is a Serbian religious and national holiday and an important date in Serbian national history.

11 Jahorina and Bjelašnica are mountains and skiing resorts outside of Sarajevo. Jahorina is located in Republika Srpska and Bjelašnica is in the Federation of Bosnia and Herzegovina.

12 Romanija is a mountainous region close to Sarajevo, now located in Republika Srpska. 
I'd dare go, particularly at night. Or, for example, when we go to Dubrovnik and drive through Gacko, where we love to stop at a restaurant for an excellent lamb roast. Gacko is located in our country, but at the entrance of the town you come across a humongous image of Draža Mihailović1 ${ }^{13}$ and all of Gacko is decorated with posters of Šešelj ${ }^{14}$.

Author: And how does that make you feel?

Alma: Frustrated and, and full of fear.

Alma's experiences produce a fear of some type of exclusion, discrimination or persecution based on ethnicity, in this case, directed towards non-Serbs. However, it is important to note that an ethnic Serb, who rejects the lionising of WWII war criminals and nationalist leaders, could also feel the same type of fear. Besides, even though Alma rejects ethnic categorisation in favour of the civic identity in her self-identification, a well-acquainted outside observer could place her into a certain ethnic category just by the sound of her first or last name and use this categorisation as a basis for discrimination, entirely independently of her self-identification. While analogous examples certainly exist in both the Bosniak and Croat areas of the country, the exclusionary nature of street names in the present example suggests that only members of a single ethnic group inhabit them. The date of 9 January ${ }^{15}$ continues to be celebrated in Republika Srpska as a national day, although the Constitutional Court of Bosnia and Herzegovina proclaimed it unconstitutional. Finally, the public celebration of ultra-nationalist leaders adds weight to the ethnicity-based fear. Alma is a $\mathrm{BiH}$ citizen and the areas she described are located in the country of her citizenship. She should feel safe and protected by her home state. Instead, she feels frustrated and afraid.

Adding more nuance to the ethnicity-based fear is a constant sense of political uncertainty in the country, felt by many of the returnees as well. Me-

13 Dragoljub Draža Mihailović was a World War II Serb royalist commander and head of the Chetnik movement, sentenced to death by Yugoslav authorities for collaboration with the Nazis. In 2015, he was rehabilitated by a court in Serbia. The controversy surrounding the rehabilitation of Draža Mihailović is beyond the scope of this paper.

14 Vojislav Šešelj is the Founder and President of the nationalist Serb Radical Party.

15 The day of 9 January is the much-disputed "Day of Republika Srpska" celebrating the establishment of this $\mathrm{BiH}$ entity during the wartime. It is regarded as unconstitutional by the Constitutional Court of $\mathrm{BiH}$ and was declared as such by a decision of 2015, followed by the annulment of referendum results on the right to celebrate this date as an official holiday. Regardless of the position of the Constitutional Court, 9 January continues to be celebrated throughout the RS, while 1 March, the official Day of Independence of Bosnia and Herzegovina is entirely ignored. 
hmed returned from Australia to live and work in $\mathrm{BiH}$, but like so many others, he is doubtful about a peaceful future.

Mehmed: Uncertainty. The uncertainty caused by a number of things, such as what we talked about before: threats of a new independence referendum and the general political situation... the uncertainty of not knowing where all of this could be going. Nobody knows whether we might have a new war, as the secession threats keep coming all of the time. On our side, our politics... we see the incompetence of our politicians to manage their own affairs and to deal with the international scene, this entire complicated set of events in the region and that points to the possibility of a new war, conflict... What exactly will happen... nobody seems to know.

Political uncertainty is a matter of daily life in $\mathrm{BiH}$, most of which is rooted in the reality of institutionalised ethnic divisions, but also aided by consistent national and international media efforts ${ }^{16}$ to keep alive an overall sense of political unpredictability representative of the generally perceived "Balkan powder keg" and the specificity of fragile peace in Bosnia and Herzegovina. In a study on emigration intentions in $\mathrm{BiH}$, Efendić (2016) finds that, contrary to conventional expectations, high unemployment and low economic growth, although important, are not the most significant drivers of emigration from $\mathrm{BiH}$. According to this study, the differences in emigration intentions between the returnee and the domicile population are not statistically significant. However, specific post-conflict factors such as "perceptions of the country's political prospects" (Efendić, 2016: 349) rank the highest.

A shared fear among citizens of all ethnic backgrounds is a fear for their economic survival. In a country with a $25.8 \%$ unemployment rate and a $55.4 \%$ youth unemployment rate, one of the highest in the world, citizens across the board live in fear of poverty and further economic decline. Ethnic divisions are exploited by local ethnonationalist elites and politicians in power to gloss over the economic deprivation and to use manufactured fear as a governing mechanism. Dobro je dok ne puca - The situation is fine, as long as the guns are quiet is an adage frequently heard in $\mathrm{BiH}$, used to keep expectations low and to prevent more serious social unrest. Anastasija, a 45-

16 Some of the more recent examples of this trend include alarmist headlines, in both Western and other media sources, such as Dudik and Kuzmanović (2018, September 12). Is Europe sleepwalking into a new Balkan war, Bloomberg, https://www.bloomberg.com/news/ features/2018-09-12/playing-with-fire-in-europe-s-powder-keg or Joksimović, N. (2018, June 7). Foreigners giving up on Bosnia: country close to collapse, Sputnik Srbija, https:// rs-lat.sputniknews.com/analize/201806071115894984-bih-izmene-izbornog-zakona-/ 
year old Serbian woman, award-winning peace activist, lawyer, and community organiser, returned from Serbia to her native Mostar, a city deeply divided between Bosniaks and Croats. ${ }^{17}$ Although she narrated a number of instances of discrimination she experienced as a Serb living in Mostar, she dismissed the possibility of future ethnic conflict and explained the current situation as caused by war-mongering politicians manipulating people's fears for votes and personal financial gain.

Instead of focusing on issues of ethnicity, Anastasija placed the greatest emphasis on the dire state of the $\mathrm{BiH}$ economy and pointed to economic hardship as her biggest source of fear.

Author: How do the frequent calls for a secession referendum in Republika Srpska or the formation of a third, Croatian entity in BiH make you feel?

Anastasija: There is no chance of that happening. It's all nonsense to me and simply a question of helping each other out win elections.

Author: You are not afraid of these threats?

Anastasija: No! Not at all.

Author: If you ever do feel afraid, what would you say causes such feelings?

Anastasija: Economic insecurity.

Author: You don't fear a new war erupting, renewed violence?

Anastasija: No, no such fears. All of that is empty talk. We won't have any wars here anytime soon. I am afraid of not being able to pay my bills and to make ends meet.

Returning to live in Mostar, a deeply divided city, to practice human rights law and promote peace activism has not been an easy task for Anastasija. Although she fits entirely into the "minority return" category, she does not view ethnic intolerance, in and of itself, as the biggest problem. She recognises the ability of self-serving populist leaders to prey on the weaknesses of a traumatised citizenry. As long as the traumas of war remain unhealed, nationalist rhetoric continues to win votes, leaving aside the pressing need for higher living standards, economic development, and growth. Anastasija's thoughts were echoed throughout Bosnia and Herzegovina during the protests of 2014 and the organisation of civic plenums to address the injustices of corrupt privatisation practices resulting in massive asset stripping and further degradation of workers' rights. In the words of Svjetlana

For more on the divisions in Mostar, see Hromadžić (2015). 
Nedimović, ${ }^{18}$ a political analyst and one of the key plenum organising figures, the protests were one of the first opportunities for citizens to find expression as part of the "social and not solely of the ethnic". Gladni smo na tri jezika - We are hungry in three languages ${ }^{19}$ was one of the most popular protest signs and a poignant summary of the state of social justice. For Anastasija and other $\mathrm{BiH}$ citizens, the state does not provide any sort of economic certainty and as such, citizenship is experienced through fear.

The abuse of political power, corruption and a general lack of the rule of law are problems of such scale in post-war $\mathrm{BiH}$ that they have become a source of fear for its citizens. The interviewees are generally very brave and resilient people, but regardless of their courageous response, a realistic basis for this fear does exist. Arif is a 56-year old Bosniak man, a survivor of Omarska, Keraterm and Trnopolje, the three concentration camps set up by Bosnian Serb forces in north-western Bosnia during the 1992-1995 war. He was expelled from Kozarac by the Army of Republika Srpska in 1992 and came to Norway as a refugee. After spending twenty years in Norway, running two successful businesses there and gaining Norwegian citizenship, he returned to his native Kozarac to start a dairy farm. Although returning to live in Republika Srpska as a Bosniak meant that he had to overcome many obstacles inherent in minority return, the greatest challenges he currently faces are the racketeering ambitions of local Bosniak politicians, with death threats attached.

Arif has recently expanded his operations to a small plant in the predominately Bosniak part of the Federation of Bosnia and Herzegovina. The small town of Arif's newest business expansion also has a sizeable Serb returnee population, some of whom are now employed by Arif's company. Arif has repeatedly rejected extortion requests from the local Bosniak politicians and, as a result, has gained considerable opposition from the local power elites. In an ironic and truly mind-boggling twist of fate, the racket-hungry Bosniak politicians have labelled Arif a "Serb-collaborator", since he gave jobs to a number of the local Serbs. He was asked how he felt when he received daily death threats from members of the corrupt ethnonationalist elite involved in racketeering efforts.

Author: Don't you ever feel afraid?

18 Interview with Svjetlana Nedimović conducted using the FAMA Methodology in 2014. Available at https://www.youtube.com/watch?v=5_LiD7qj0pQ

19 The three official languages of Bosnia and Herzegovina: Bosnian, Croatian, and Serbian. 
Arif: What am I supposed to fear? When you've managed to load a truck of 350 dead bodies in one day, collecting body parts as you go along, you also understand that a human being, upon losing the ability to reason, becomes more ferocious than any beast. Isn't that true? Whom am I supposed to fear anymore?

Author: I am not saying that you should be afraid. I am just asking whether you are afraid?

Arif: $\quad W h y$ should I be? What else can they do to me? They say that they will put me two meters under, because that's what happens to the disobedient and that they have their people to take care of business. Whenever I hear such talk, I immediately ask when and where? Would you like to do it in downtown Bihać? Would you like to blow up my car? Would you like to throw me in to the river with a rock tied around my neck? What do you want from me? I employ Serb returnees. Well, of course I do. That is only natural, I am a returnee, too. They say that I give jobs to chetniks, well the only kind of division I recognise is the one where we ask ourselves: are we human? Whenever they threaten me, whenever they say that they will make me disappear, I openly talk about their crime and corruption. Courage. Courage is the answer. You need to be brave in this country, more so now than during the camps.

Arif's life story is truly inspirational from many different perspectives: an ability to overcome hardly imaginable circumstances during wartime, a post-war commitment to building a multi-ethnic and peaceful society, an orientation towards progress and development and remarkable courage in the face of post-war threats.

The home state, on the other hand, has failed Arif at least twice - during wartime and in peacetime. The state apparatus was not strong enough to protect Arif from the horror of Bosnian Serb-run concentration camps nor is it strong enough now to protect Arif from death threats by corrupt Bosniak politicians. In either case, while Arif has the basis to constitute his $\mathrm{BiH}$ citizenship through fear, he chooses to be brave in to the face of the state, which is not designed to keep its citizens safe. Besides, the finding that wartime experience is featured prominently within the returnees' motivation for return confirms previous studies of voluntary return to $\mathrm{BiH}$, such as Porobić (2012) and Porobić (2017). In her more recent study, Porobić (2017: 120) finds "clear interlinkages between trauma, remembrance, and return motivations and experiences". She connects these findings with her previ- 
ous work with Bosnian refugees in Sweden, where she discovered that resilience was directed towards a state of "in-betweenness" and that attitudes towards return varied from viewing it is a form of healing the trauma of displacement to seeing it as a possible source of new traumatisation. Arif, similarly to other participants in this study, continues to live and work in the home state, regardless of the obstacles he encounters, mainly due to his individual agency, courage, and dedication and in spite of a state structure set up to defeat its citizens. The abuse of political power and the fear it creates are important elements of the everyday experience of $\mathrm{BiH}$ citizenship. While fear forces some to leave the country and join over two million $\mathrm{BiH}$ citizens living abroad, others choose to stay and show great courage in facing the challenges of life in Bosnia, perhaps greater than what was required during the wartime.

Facing fear and daily threats of violence and choosing to be brave is also Ema's strategy for making her return to her small hometown in northern Bosnia a success. She is a 35-year old former marketing executive, who refuses the standard ethnic and religious categories and refers to herself as European regarding her ethnic background and Christian ${ }^{20}$ in terms of her faith. Ema left the comfort of a corporate job in Austria, determined to grow an organic herb farm in the BiH entity of Republika Srpska. She came back by herself, while most of her family members still reside in Austria. When asked about her attitude towards fear, she narrated her direct and daily experience with violence and threats of violence.

Ema: No, I am not afraid. I know this sounds strange, but I just expect that somebody would attack me here, even physically. One of the first arrangements I made with my family is what would happen to the farm if something were to happen to me.

[We both get teary-eyed and stop the conversation for a couple of moments so that we could collect ourselves and continue our interview. I look at her with partial disbelief and shock.]

Ema: Yes, I am serious. I get emotional, because I am tired of the daily struggle. I am tired, but I am not afraid. I told you. I simply knew from the beginning what is it that I am getting myself into and I had a long talk about it with my family. This is all because we found weapons and unexploded shells in our fields. Any day, I could step onto a

20 She rejects categorisation within either the Catholic or the Orthodox Church, as well as religious practice and organised religion. However, she considers the teachings and values of Christianity to be guiding principles of her life. 
mine, while we plow the fields. If I were to step onto it, it would all be finished, end of the story. I wouldn't need to get shot by anybody. An unexploded mine would be enough to do the job. Although, I also experienced being attacked right in front of the office.

Author: What happened?

Ema: $\quad$ A half-drunk guy walked up to me angrily, yelling and waving a brick in his hand, getting ready to throw it at the front office.

"What is this green colour on your door? Is this some kind of a Muslim joint?' - he screamed at me in rage.

I asked whether he was literate and if so, that he could read what our company is all about as it is described on our front door. He kept waving his brick at me and moved back after hurling a few more slurs and insults. He was referring to the green colour of our company branding, the colour of grass, vegetables, fruit, you know. We produce organic healing herbs and we use the colour green for our advertising, a natural choice for us. I just simply could not believe that the war hasn't taught us anything. I sometimes feel that we would be ready to get back to guns and attack our next-door neighbour again.

Author: Did you report the incident to the police?

Ema: Oh no, no. People here have advised me that I should not contact the police. I did that when I noticed that lumber was being stolen from a forest next to our fields. I called the police to report the theft, but I was later told that this is not how life works here. I was warned not to call the police too often, that is unless I wanted my fields burnt to the ground in retaliation.

When asked whether she was happy to have returned, Ema responded with a resounding "Yes, of course!" From her tone, it was not clear whether she was being ironic or serious so the question was rephrased to ask whether she would consider her return to $\mathrm{BiH}$ to be successful. Re-affirming her initial answer, and leaving the author entirely perplexed, she said "Fantastic!"

Ema is a 35-year old woman with an extremely positive attitude towards life and her business. She wants to contribute to her home state and make a positive difference. Yet, we both started crying when she mentioned the discussion she had with her family about the future of her company in case something were to happen to her. Ema is very well aware of the dangers of living and working in a state that is not there to protect or support her. Her daily experience of citizenship is one filled with fear, while her response to 
the presence of fear is one of courage. She says she is not afraid, because she refuses to acknowledge the fear. She responds with courage to threats of violence, ethnic slurs and a general sense of insecurity, where calling the police might result in retaliation. She continues to pursue her dream of planting and harvesting healing organic herbs in the face of fear as a key emotion constituting the citizenship of her home country.

\section{CONCLUSION}

The initial claim of this paper is that voluntary return to a post-conflict society like Bosnia and Herzegovina is primarily emotionally motivated. This is particularly true given the overall failure of sustainable minority or majority return policies in Bosnia and Herzegovina, and the continuation of staggering emigration rates. The paper argues that the motivation for voluntary return is emotional and that these emotions are distinct and highly diversified, ranging from fear, shame, and guilt to patriotic love, pride, nostalgia, and joy. The returnees, who in many cases are dual citizens, thus have a unique perspective on the emotional dimension of their home citizenship. Besides, participants in the study were selected keeping in mind the specific criteria of exercising freedom of choice when making their decision to return to $\mathrm{BiH}$. In other words, the returnees were under no legal, political, social or financial pressure to return. They were also not part of any assisted repatriation policy or programme designed to promote return. While exploring the distinct emotions constituting $\mathrm{BiH}$ citizenship, two premises anchored this study. Firstly, emotions are not starkly opposed to rationality and thus are given their rightful place in social analysis. Secondly, emotions are not purely personal, but instead, are considered crucial for the understanding of social reality. The theoretical foundations of this paper are set within the scholarly literature (Marcus, 2002; Ho, 2009; Jackson, 2016; Magat, 1999; Wood, 2013; Howes and Hammett, 2016; Ahmed, 2016) dealing with connections between citizenship and emotions.

This paper investigated how the emotion of fear acts to constitute the emotional dimension of citizenship, as illustrated by voluntary return migration to Bosnia and Herzegovina, a post-conflict society. The connection between citizenship and fear has three identifiable dimensions: ethnic intolerance, economic insecurity and the abuse of political power. Each of the dimensions of fear as it constitutes $\mathrm{BiH}$ citizenship was related to its origin - the two-tiered citizenship regime of Bosnia and Herzegovina and the consti- 
tutional setup enshrined in the Dayton Peace Agreement (DPA). Although Annex 7 provisions of the DPA were considered, given the reality of failed policies of sustainable return, it could be concluded that the DPA de facto legalised ethnic cleansing and genocide, entrenching ethnic divisions and thus promulgating the ethnicity-based fear. Furthermore, the bureaucratic structure envisioned by the DPA does not create favourable conditions for economic growth and development and acts to increase economic insecurity as a key dimension of citizens' fear. Finally, the DPA created significant power vacuums within the $\mathrm{BiH}$ state structure, thus providing plenty of room for corruption, intimidation, and racketeering. Under such circumstances, the rule of law becomes an exception, while the abuse of political power by oligarchic ethnonationalist elites is the effective norm. The fear of the abuse of political power, thus, becomes a key component of the emotional dimension of $\mathrm{BiH}$ citizenship.

The argument that fear constitutes $\mathrm{BiH}$ citizenship and that this relationship is inherent in the DPA Constitution was supported by an inductive thematic analysis of 35 in-depth interviews with returnees. The returnees are people who have voluntarily decided to leave the relative comfort of the lives they had managed to build for themselves in a variety of host countries such as Germany, the U.S., Australia, Austria or Switzerland, so that they could attempt to rebuild their war-torn past and contribute to the rebuilding of their home country. As was demonstrated throughout the paper, their response to the overwhelming presence of fear as a key emotion constituting $\mathrm{BiH}$ citizenship is to persist in their efforts with determination and courage. While acknowledging the various dimensions of the fear they feel as citizens, they are not deterred. However, it is important to note that their courage and determination is solely the result of their own agency. The ultimate success of their return is not due to the state structure, but in spite of the obstacles it creates. In that sense, citizenship constituted by fear is a direct result of the $\mathrm{BiH}$ state structure, engrained in the DPA, a peace agreement which stopped a horrific war, while failing to create the conditions for a long-term and prosperous peace. 


\section{REFERENCES}

Aguilar, F. V. (1996). The dialectics of transnational shame and national identity, Philippine Sociological Review, 44 (1/4): 101-136.

Ahmed, S. (2014). The cultural politics of emotion. Edinburgh: Edinburgh University Press.

Ahmed, S. (2016). Citizenship, Belonging and Attachment in the "War on Terror", Critical Criminology, 24 (1): 111-125, doi: https://doi.org/10.1007/s10612-015-9279-2

Alvarez, M. del P. V. (2015). Annex 7: why are we still discussing it?, Forced Migration Review, 50: 6-7.

Bieber, F. (2016). Conclusion Bosnia and Herzegovina: A Failed Success, in: S. Keil and V. Perry (eds). State-building and democratization in Bosnia and Herzegovina. London: Routledge, 213-220.

Bleiker, R. and Hutchison, E. (2008). Fear no more: emotions and world politics, Review of International Studies, 34 (S1): 115-135, doi: https://doi.org/10.1017/S0260210508007821

Brković, Č. (2015). Management of ambiguity: Favours and flexibility in Bosnia and Herzegovina: Management of Ambiguity, Social Anthropology, 23 (3): 268-282, doi: https://doi.org/10.1111/1469-8676.12211

Brown, J. (2014). "Our National Feeling is a Broken One": Civic Emotion and the Holocaust in German Citizenship Education, Qualitative Sociology, 37 (4): 425-442, doi: https://doi.org/10.1007/s11133-014-9286-8

Collyer, M. (2013). Emigration Nations - Policies and Ideologies of Emigrant Engagement. London: Palgrave Macmillan.

Dahlman, C. and Ó Tuathail, G. (2005). The legacy of ethnic cleansing: The international community and the returns process in post-Dayton Bosnia-Herzegovina, Political Geography, 24 (5): 569-599, doi: https://doi.org/10.1016/j.polgeo.2005.01.007

De Graeve, K. (2010). The limits of intimate citizenship: Reproduction of difference in Flemish-Ethiopian "adoption" cultures, Bioethics, 24 (7): 365-372, doi: https://doi. org/10.1111/j.1467-8519.2010.01830.x

Džankić, J. (2015). The Politics of Inclusion and Exclusion: Citizenship and Voting Rights in Bosnia and Herzegovina, International Peacekeeping, 22 (5): 526-544, doi: https:// doi.org/10.1080/13533312.2015.110008

Eastmond, M. (2006). Transnational Returns and Reconstruction in Post-war Bosnia and Herzegovina, International Migration, 44 (3): 141-166, doi: https://doi.org/10.1111/ j.1468-2435.2006.00375.x

Efendić, A. (2016). Emigration intentions in a post-conflict environment: evidence from Bosnia and Herzegovina, Post-Communist Economies, 28 (3): 335-352, doi: https://doi. org/10.1080/14631377.2016.1166800

Fortier, A.-M. (2010). Proximity by design? Affective citizenship and the management of unease, Citizenship Studies, 14 (1):17-30, doi: https://doi.org/10.1080/13621020903466258

Franz, M. (2015). Will to love, will to fear: the emotional politics of illegality and citizenship in the campaign against birthright citizenship in the US, Social Identities, 21 (2): 184-198, doi: https://doi.org/10.1080/13504630.2015.1041016

Helms, E. (2013). Innocence and Victimhood: Gender, Nation, and Women's Activism in Postwar Bosnia-Herzegovina. Madison: University of Wisconsin Press.

Ho, E. L.-E. (2009). Constituting Citizenship through the Emotions: Singaporean Transmigrants in London, Annals of the Association of American Geographers, 99 (4): 788-804. 
Howes, L. and Hammett, D. (2016). Negotiating identities and emotional belonging: Shan in northern Thailand, Emotion, Space and Society, 19: 21-28, doi: https://doi. org/10.1016/j.emospa.2016.04.001

Hromadžić, A. (2015). Citizens of an Empty Nation: Youth and State-Making in Postwar Bosnia-Herzegovina. Philadelphia: University of Pennsylvania Press.

Hutchinson, E. and Bleiker, R. (2007). Emotions in the war on terror, in: A. Bellamy, R. Bleiker, S. Davies and R. Devetak (eds). Security and the War on Terror. London: Routledge, 57-70.

Isin, E. F. (2004). The neurotic citizen, Citizenship Studies, 8 (3): 217-235, doi: https://doi. org/10.1080/1362102042000256970

Jackson, L. (2016). Intimate citizenship? Rethinking the politics and experience of citizenship as emotional in Wales and Singapore, Gender, Place and Culture, 23 (6): 817-833, doi: https://doi.org/10.1080/0966369X.2015.1073695

Jansen, S. (2015). Yearnings in the meantime: "normal lives" and the state in a Sarajevo apartment complex. New York: Berghahn Books.

Johnson, C. (2010). The politics of affective citizenship: from Blair to Obama, Citizenship Studies, 14 (5): 495-509, doi: https://doi.org/10.1080/13621025.2010.506702

Laszczkowski, M. and Reeves, M. (2015). Introduction: Affective States-Entanglements, Suspensions, Suspicions, Social Analysis: The International Journal of Social and Cultural Practice, 59 (4), 1-14, doi: https://doi.org/10.3167/sa.2015.590401

Magat, I. N. (1999). Israeli and Japanese Immigrants to Canada: Home, Belonging, and the Territorialization of Identity, Ethos, 27 (2): 119-144, doi: https://doi.org/10.1525/ eth.1999.27.2.119

Marcus, G. E. (2002). The sentimental citizen: Emotion in Democratic Politics. University Park: The Pennsylvania State University Press.

MasGiralt, R. (2015). Socio-cultural invisibility and belonging: Latin American migrants in the north of England, Emotion, Space and Society, 15: 3-10, doi: https://doi. org/10.1016/j.emospa.2015.03.002

Nyers, P. (2007). Introduction: Why Citizenship Studies, Citizenship Studies, 11 (1): 1-4, doi: https://doi.org/10.1080/13621020601099716

Pantti, M. and van Zoonen, L. (2006). Do Crying Citizens Make Good Citizens?, Social Semiotics, 16 (2): 205-224, doi: https://doi.org/10.1080/10350330600664797

Pašić, L. (2015). Political and social consequences of continuing displacement in Bosnia and Herzegovina, Forced Migration Review, 50: 7-9.

Porobić, S. (2012). Resilience and Religion in a Forced Migration Context: A Narrative Study of Religiousness as a Resilience Factor in Dealing with Refugee Experiences from a PostMigration Perspective of Bosnian Refugees in Sweden. Lund: Lund University.

Porobić, S. (2017). "Invisible" returns of Bosnian refugees and their psychosocial wellbeing, in: Z. Vathi and R. King (eds). Return Migration and Psychosocial Wellbeing: Discourses, Policy-Making and Outcomes for Migrants and their Families. London - New York: Routledge - Taylor \& Francis, 108-126.

Portes, A., Guarnizo, L. E. and Landolt, P. (1999). The study of transnationalism: pitfalls and promise of an emergent research field, Ethnic and Racial Studies, 22 (2): 217-237, doi: https://doi.org/10.1080/014198799329468

Skulte-Ouaiss, J. (2013). Home is where the heart is; citizenship is where it is safe: dual citizenship and Europe, Identities, 20 (2): 133-148, doi: https://doi.org/10.1080/10702 89X.2012.763166 
Stoler, A. (2007). Affective States, in: D. Nugent and J. Vincent (eds). A companion to the anthropology of politics. Oxford: Blackwell, 4-20.

Strauss, A. and Corbin, J. (1998). Basics of Qualitative Research: Techniques and Procedures for Developing Grounded Theory. Newbury Park: Sage.

UNDP (2014). Emigration and development of Bosnia and Herzegovina BEST PRACTICES. May 9, 2017, http://www.ba.undp.org/content/bosnia_and_herzegovina/en/home/ library/poverty/iseljeni_tvo-i-razvoj-bosne-i-hercegovine---uspjeni-primjeri.html (20 November 2018).

Wood, B. E. (2013). Young people's emotional geographies of citizenship participation: Spatial and relational insights, Emotion, Space and Society, 9: 50-58, doi: https://doi. org/10.1016/j.emospa.2013.02.004

World Bank (2017a). Unemployment: Youth Total, April 28, 2017 http://data.worldbank. org/indicator/SL.UEM.1524.ZS (20 November 2018).

World Bank (2017b). Bosnia and Herzegovina Country Snapshot. http://pubdocs. worldbank.org/en/705141492622353847/Bosnia-Herzegovina-Snapshot13Apr2017. pdf (20 November 2018).

Yuval-Davis, N. (2006). Belonging and the politics of belonging, Patterns of Prejudice, 40 (3): 197-214, doi: https://doi.org/10.1080/00313220600769331

Yuval-Davis, N., Kannabirān, K. and Vieten, U. (2006). The Situated Politics of Belonging. London: SAGE Publications. 


\title{
Suočiti se sa strahom i odgovoriti hrabrošću: razumijevanje uloge emocije straha $u$ konstitutiranju »emotivne dimenzije« državljanstva pripadnika iseljeništva koji su se dobrovoljno vratili u Bosnu i Hercegovinu
}

\section{Aida Ibričević}

\begin{abstract}
SAŽETAK
Ovaj rad razmatra slučaj dobrovoljne povratne migracije u postkonfliktno društvo, kao što je to Bosna i Hercegovina $(\mathrm{BiH})$, kada se povratnik, iako ima pravnu, ekonomsku i društvenu mogućnost da ostane živjeti i raditi u inozemstvu, svojevoljno odluči vratiti. Početna je tvrdnja rada da je osnovna motivacija za ovakvu vrstu migracije emotivne prirode i da, iako duboko istražena emocija »patriotske ljubavi« (Brown, 2014) čini značajan dio povratničke emotivne strukture, i druge emocije igraju jednaku, a u nekim slučajevima i važniju ulogu. Autoričin je argument da je strah jedna od ključnih emocija koje konstituiraju povratničko svakodnevno iskustvo državljanstva te navodi tri dimenzije straha: etničku diskriminaciju, ekonomsku neizvjesnost i zloupotrebu političke moći. Činjenica da povratnici nastavljaju živjeti i raditi u Bosni i Hercegovini čin je njihove velike hrabrosti, a uspjeh njihova povratka nije uvjetovan državnom strukturom predviđenom Daytonskim mirovnim sporazumom, koji uključuje i sadašnji ustav $\mathrm{BiH}$, nego se događa usprkos svim preprekama koje ovakva državna struktura podrazumijeva. Autorica svoje zaključke temelji na tematskoj kvalitativnoj analizi podataka iz 35 dubinskih intervjua s pripadnicima bosanskohercegovačkog iseljeništva koji su se dobrovoljno odlučili vratiti i ponovo nastaniti u BiH.
\end{abstract}

KLJUČNE RIJEČI: »emotivne dimenzije« državljanstva, strah, dom, pripadanje, povratne migracije, Bosna i Hercegovina 